Article

\title{
The Use of Personal Value Estimations to Select Images for Preservation in Public Library Digital Community Collections
}

\author{
Andrea Copeland \\ Department of Library \& Information Science, School of Informatics and Computing, \\ Indiana University, 755 W Michigan Street, UL3100C, Indianapolis, IN 46202, USA; \\ E-Mail: ajapzon@iupui.edu; Tel.: +1-317-274-0114; Fax: +1-317-278-7669
}

Received: 7 February 2014; in revised form: 23 April 2014 / Accepted: 7 May 2014 /

Published: 27 May 2014

\begin{abstract}
A considerable amount of information, particularly in image form, is shared on the web through social networking sites. If any of this content is worthy of preservation, who decides what is to be preserved and based on what criteria. This paper explores the potential for public libraries to assume this role of community digital repositories through the creation of digital collections. Thirty public library users and thirty librarians were solicited from the Indianapolis metropolitan area to evaluate five images selected from Flickr in terms of their value to public library digital collections and their worthiness of long-term preservation. Using a seven-point Likert scale, participants assigned a value to each image in terms of its importance to self, family and society. Participants were then asked to explain the reasoning behind their valuations. Public library users and librarians had similar value estimations of the images in the study. This is perhaps the most significant finding of the study, given the importance of collaboration and forming partnerships for building and sustaining community collections and archives.
\end{abstract}

Keywords: public libraries; digital collections; community archives; digital preservation; social history; social media; images; photographs; librarians; library users

\section{Introduction}

A considerable amount of information is shared on the web through social networking sites, blogs and personal web pages. One begins to wonder if any of this content is worthy of preservation. Research has found that individuals share digital content that is valuable to them for a variety of reasons $[1,2]$. However, is it valuable to others? To friends? To family? To society as a whole? 
If so, what is the value and to whom is it valuable? If it is valuable, then we are at risk of losing this content by not taking steps to collect, organize and preserve it. Who is responsible? Are memory organizations, such as libraries, archives and museums, responsible for preserving this kind of social historical record? Who decides which content is of significant value?

Archivists deem items of value to be worthy of preservation and future reuse. It is the archivist's concept of value that is to be utilized in this study. Valuable information and artifacts are identified for preservation. Further, the archival concepts of primary and secondary value are relevant. Primary value is associated with the original purpose the information was created for, and secondary value is associated with reuse and other purposes that evolve over time.

Individuals who share content on the web can help identify publicly available digital content of value and help determine if it is worthy of preservation. These individuals have the potential to guide memory organizations in the processes of creating and organizing freely available digital images representing content of social value $[3,4]$. Further, these individuals can help organizations determine the categories of images valued for preservation. This paper presents an exploratory study involving public library users and librarians and the values they attributed to images belonging to others posted on Flickr. The findings illustrate the potential influence individual value estimations could have on the creation of public library digital cultural heritage collections.

Furthermore, the findings presented here are part of a larger study that contains three related, but separate parts. The three parts taken together provide an opportunity to explore the value of personal content and its relationship to technology, privacy and social significance. For a detailed discussion on the context of the larger study, please see Section 4.1.

\section{Basis for Exploration}

Social networking sites, like Facebook, which allow for the creation of personal and social archives, have been accused of commercializing and homogenizing public memory and the cultural record $[5,6]$. Others assert that there is much for cultural institutions to gain from understanding the practices of those who use corporate social networking sites. Current user practices can inform the curation endeavor by making institutional (memory organizations) social media collections useful, interesting and used [4,7]. This paper's author takes the perspective of individuals and cultural institutions working together in a social networking capacity to preserve public memory through the co-creation of community repositories [8]. Community members contribute the content that documents local history, and the cultural institution provides the technical and legal knowledge and infrastructure for its organization and preservation.

For libraries and other memory organizations to create a sustainable infrastructure for digital collections or archives, they must collaborate with each other, create interoperable systems and develop standards for the creation, storage and reuse of digital content $[9,10]$. For the collection and preservation of personal information of value to the social and cultural record by memory organizations, individuals need to be part of the collaboration effort [11]. In the United Kingdom, in an effort to be inclusive of groups historically marginalized in formal institutional archival collections, heritage professionals have partnered with community archives representing these groups [12,13]. 
These partnerships have served to democratize and diversify archival collections, thereby documenting and preserving a new social history along with the established political and diplomatic histories [14].

Realizing the importance of this new social history (the people's history), archives have developed outreach programs to create partnerships and to facilitate the inclusion of underrepresented groups in institutional archives in a manner that is participatory and community centered $[12,15]$. In creating these collaborations between institutional and community archives, the importance of archival practices and policies, such as appraisal, description and collection development guidelines, need to be considered anew, given the perspective that community members are the creators and experts of their own archives [16,17]. Individuals or grassroots organizations partnering with the establishment (be it an institutional archive, government agency for urban planning or a non-profit agency providing social services) to co-create services and resources have been found to be marginalized or disadvantaged in the process $[18,19]$. Given the importance of creating collections that reflect the community and its members, this study seeks to understand if library professionals and library users - the potential collaborators in co-creation - had similar estimations of items valued for preservation.

While much has been written about community archives from the point of view of underrepresented groups and collaboration with institutional archives, little has been written about the potential for public libraries to contribute to the documentation and preservation of local community heritage. Public libraries and their communities reflect one another, and the importance of public libraries as community centers continues to grow [20-23]. However, there has been little activity with regards to the development of community archives or collections with regards to digital content. In the United States, it is not uncommon for public libraries to house physical local history collections and local genealogical information. The Denver Public Library and the Pasadena Public Library are two examples of libraries working with community members to document the histories of their communities through digital media collections; this encourages community members to contribute to the telling and documenting of their community's history [24].

The role of the public library as a facilitator of the creation, publication and distribution of user-generated digital media is evolving [25-27]. Libraries are assisting users with the publication of self-created and community-created works. The importance of this role for public libraries is heightened by the change in the production of information creation, distribution and access. Unique content will make one public library or other information portal different from the next. Local communities are bound by specific physical geography, industry, history, culture and people. What is more unique than the individual community served by its public library?

While there are examples to point to in practice, little research has been conducted in regards to understanding the legal, social, historical, cultural and technical infrastructure considerations needed for the development of digital collections in participatory and community-centered public libraries. Lipinski and Copeland provide a legal analysis of existing social networking sites' terms of services for the appropriateness of use by public memory institutions and in doing so, conclude that these existing terms of service can inform those used by public libraries. However, because they do not sufficiently address First Amendment and digital preservation concerns, public libraries cannot adopt them or use their services to support community collections [28]. Legal issues can be more cut-and-dried than the value judgments associated with selection, appraisal, description and access to user or community-generated content. 
This study explores the notion of public libraries developing digital collections that document and preserve the local heritage of their communities as it is happening, rather than providing an after-the-fact historical collection documenting what has already happened in a community. The reason being is that with digital content, preservation and creation must be considered at the same time to ensure that file formats, metadata and system inter-operability used in the creation process will also support long-term access to the digital content being created [29]. If there is a past to be studied that is primarily documented digitally, then archival considerations need to co-exist with creation. For example, The Library of Congress has collected billions of tweets from the social media site, Twitter, and downloaded them to a storage location. The tweets are, for all practical purposes, inaccessible, because they are not contained in any sort of functional digital collection.

Community archives can be defined in many ways. Some examples include regionally-based communities [30-32] and historically underrepresented communities that are born of discrimination based on race, social and economic status or sexual orientation [33-37]. For the purpose of the research presented here, the community recorded at the largest level is the city of Indianapolis, and at the smallest level are the various neighborhoods served by the branches of the Indianapolis Public Library. The community is defined foremost by its region and secondarily by the social, political, cultural and economic factors influencing the region. For the purpose of the study, the concept of archives within this community context is described as public library digital collections, including images worthy of long-term preservation.

Five images, specifically photographs, were selected from Flickr for use in the study. Photographs, rather than text or sound, were selected, as they capture and document life's experiences in a manner that is more readily understandable to those experiencing them than the other formats. In Susan Sontag's influential work, On Photography, she describes painting and texts as narrowly selective interpretations and photographs as narrowly selective transparencies [38]. This transparency provides evidence of what has happened. Sontag's notion that "photographs really are experience captured" is further developed in the work of Alison Landsberg. The concept of prosthetic memories describes the phenomenon by which individuals internalize memories of events that they did not live because of their increasing ability to engage with technologies that allow for a rich sensory experience of surrogate representations of events [39]. This concept is relevant to this study, as these prosthetic memories are likely to influence value estimations of such surrogates.

Lastly, photographs have presented significant challenges to archivists and information retrieval experts alike. Most information organizational systems are based on textual classifications and within the bibliographic tradition. Institutional archives have long struggled with how to classify photographs, focusing on factual significance rather than the contextual meanings or the functional origins of the photographed subject $[40,41]$. This study has the potential to provide insights into the role of contextual descriptors for photographs.

There is much existing discourse on public or collective memory and its relationship to physical space and to representations of history; for example, the works of Jacques Derrida and the archival functions of forgetting and remembering in the creation of history and fiction; of Maurice Halbwachs and the influence of place on memory and meaning; of Alison Landsberg and the experience of prosthetic memory; and of Pierre Nora and the relationship between living memory and reconstructed history. These works are relevant to the interpretation of this study's findings. As this is an exploratory 
study, the relevance of this discourse has emerged from the analysis. Given the nature of the study design, this reflection will evolve over time and in conjunction with the analysis of the larger study.

\section{Research Questions}

Given the documented importance of collaboration between formal institutions and informal groups of individuals, this research compares the views of library users and librarians and other library workers with regards to valuing images shared through social media sites for preservation and inclusion in public library digital collections. Further, because of the exploratory and developmental nature of public library digital archival collections, the study examines the considerations that influence content valued for the inclusion in such collections and the reasons for doing so. By comparing the perceptions of library professionals and library users and exploring their value estimation influences, this study hopes to provide support for the notion that community repositories can be co-created.

1. Do public library users and library professionals value images posted to social media differently?

2. What considerations influence digital images valued for inclusion in image collections in public libraries and why?

\section{Methods}

\subsection{Context of Larger Study}

The findings presented here are part of a larger study that contains three related, but separate parts. The three parts taken together provide an opportunity to explore the value of personal content and its relationship to technology, privacy and social significance.

In the first part, participants were asked to describe any differences in the types of information they store on digital devices, private web locations and the open web and the reasoning for the differences. These questions were designed to understand privacy concerns, motivations for sharing information on the web and the degree to which the private web or personal cloud computing was replacing digital devices as the preferred storage location for personal information. Additionally, the participants were asked to compare the three locations given their effectiveness at insuring privacy, preventing file corruption, easing access for reuse, securing valuable information and preventing loss.

In the second part of the study, participants were asked to discuss with the author five images that they had shared and five images that had been shared with them through social networking sites. The participants were then asked to describe if and how the photos were valuable to them, their family history, social history, how long the images should be preserved and if they belonged in a public library digital collection. These questions were designed to provide an understanding of the degree to which personal content shared publicly reflected importance outside of the personal context.

In the third part, the part presented here, the participants were asked to evaluate the five images the author selected from Flickr. The same questions posed to the participants in part two are posed again in part three. This time, the intention was to understand the extent to which publicly available images were of value to them personally and to their idea of social history. 


\subsection{Participants}

Thirty public library users and thirty librarians were solicited from the Indianapolis metropolitan area to participate in this study. Study participants were recruited in the following ways: an announcement on the Indianapolis Public Library Facebook Page, an announcement on the Indiana University Purdue University Indianapolis (IUPUI) electronic newsletter and an announcement on the Indiana Public Library email list. Additionally, snowballing was utilized, particularly in the case of recruiting library professionals. Data was collected from July, 2012, to October, 2012. Library professionals include individuals with accredited master's degrees, as well as other library workers, as it is not uncommon for libraries to employ a host of other professional and support staff members who perform a diversity of tasks related to public services and collection building. The Indiana University Institutional Review Board approved the study, and each of the participants received $\$ 25$.

Both public library users and librarians were included in the study to examine how their views on content value estimation varied. If users and librarians had strongly differing views on what was appropriate for inclusion in public library collections, then the potential for such co-created collections would be limited. In other words, producers of content and producers of collections need to have a similar level of influence over such collections if they are to be a part of memory institutions.

Tables 1 and 2 provide detailed demographic information for each of the study participants - public library users and library professionals, respectively. All names are pseudonyms. Participants are arranged by age from oldest to youngest, with numerical data representing age in years. Regarding the level of education obtained, MA indicates any Master's Degree and BA any Bachelor's Degree. Using SM indicates years using social media networks. The two groups have similar averages in terms of age: 33 years for both. Results are similar for users and library professionals in other categories, as well: PC use (14 and 18 years, respectively), using SM (7 and 8 years) and using public libraries (23 and 29 years). Given the professional bias, it is not surprising that library professionals have slightly higher averages for personal computers, social media and public library usage.

\subsection{Data Collection and Analysis}

Each participant was asked to evaluate 5 images, which the author selected from Flickr to represent community, family life, art and politics. Using a 7-point Likert scale (with $1=$ strongly disagree and 7 = strongly agree), they were asked to evaluate the images by responding to the following questions: Is it valuable to me? Is it valuable to social history? Should it be preserved indefinitely? Should it be preserved for no longer than 5 years? Should it be preserved for no longer than a year? Should it not be preserved at all? Does it belong in a public library digital collection?

In addition to using the Likert scale questions to assess how the participants valued each of the images, the author asked the participants the following questions: Please tell me what, if any, value this image has for you? Do you think this image is appropriate for inclusion in a public library digital collection? Should this image be preserved for long-term use; why or why not? Would additional information about this image help you decide its value? If so, what would that information be? 
Table 1. Characteristics of participants: public library users.

\begin{tabular}{|c|c|c|c|c|c|c|c|c|}
\hline Name & Gender & Race & Age & Education & $\begin{array}{l}\text { PC use } \\
\text { (years) }\end{array}$ & $\begin{array}{c}\text { Using SM } \\
\text { (years) }\end{array}$ & $\begin{array}{c}\text { Using public } \\
\text { libraries (years) }\end{array}$ & $\begin{array}{c}\text { Frequency of } \\
\text { public library use }\end{array}$ \\
\hline Paul & $M$ & White & 52 & MA & 25 & 5 & 47 & Every few months \\
\hline Sally & $\mathrm{F}$ & White & 48 & $\begin{array}{c}\text { BA, some } \\
\text { graduate }\end{array}$ & Yes & 2 & 10 & Twice weekly \\
\hline Gloria & $\mathrm{F}$ & White & 48 & 1 year & 10 & 10 & 30 & Biweekly \\
\hline Karl & $\mathrm{M}$ & White & 46 & MA & 28 & 5 & $40+$ & Monthly \\
\hline Clark & $\mathrm{M}$ & White & 46 & 1 year & $20+$ & 7 & $40+$ & Once monthly \\
\hline Rita & $\mathrm{F}$ & White & 43 & MA & 15 & $2 / 3$ & 35 & Once monthly \\
\hline Jessica & $\mathrm{F}$ & White & 38 & 2 years & 7 & 12 & 35 & Biweekly \\
\hline Caleb & $\mathrm{M}$ & White & 38 & BA & 25 & $<1$ & 30 & Once monthly \\
\hline Yasmia & $\mathrm{F}$ & White & 38 & $\begin{array}{l}\text { BA, some } \\
\text { graduate }\end{array}$ & 20 & 5 & 38 & Weekly \\
\hline Alice & $\mathrm{F}$ & White & 37 & BA & 10 & 2 & 30 & 2-3 times weekly \\
\hline Kathleen & $\mathrm{F}$ & $\begin{array}{l}\text { Pacific } \\
\text { Islander }\end{array}$ & 36 & BA & 18 & 2 & 35 & Once monthly \\
\hline Henry & $\mathrm{M}$ & White & 35 & BA & 16 & 15 & 30 & Every few months \\
\hline Fred & M & White & 35 & $\begin{array}{l}\text { BA, some } \\
\text { graduate }\end{array}$ & 20 & 3 & 12 & Every few months \\
\hline Vicky & $\mathrm{F}$ & White & 31 & BA & 12 & 7 & 15 & Weekly \\
\hline Boris & $\mathrm{M}$ & White & 31 & 1 year & 17 & 3 & 12 & Every other day \\
\hline Ethan & $\mathrm{M}$ & White & 29 & BA & 23 & 10 & 25 & Once a year \\
\hline Ike & M & $\begin{array}{l}\text { African- } \\
\text { American }\end{array}$ & 29 & HS & 5 & 10 & 20 & Rarely \\
\hline Will & $\mathrm{M}$ & White & 28 & MA & 12 & 8 & 6 & Twice monthly \\
\hline Gerald & M & White & 27 & MA & 20 & 8 & 4 & Infrequently \\
\hline Melissa & $\mathrm{F}$ & White & 27 & MA & 13 & 7 & 20 & Weekly \\
\hline Lucy & $\mathrm{F}$ & $\begin{array}{l}\text { African- } \\
\text { American }\end{array}$ & 27 & 1 year & 12 & 10 & 12 & Once a month \\
\hline Sean & M & White & 26 & BA & 9 & 6 & 13 & Daily \\
\hline Zoey & $\mathrm{F}$ & $\begin{array}{l}\text { African- } \\
\text { American }\end{array}$ & 24 & 2 years & $10+$ & $10+$ & 24 & Monthly \\
\hline Valerie & $\mathrm{F}$ & White & 24 & 1 year & 12 & 10 & 24 & Weekly \\
\hline Quenby & $\mathrm{F}$ & $\begin{array}{l}\text { African- } \\
\text { American }\end{array}$ & 24 & 2 years & 13 & 9 & 19 & Once monthly \\
\hline Xena & $\mathrm{F}$ & Asian & 23 & $\mathrm{BA}$ & 15 & 17 & 18 & Twice yearly \\
\hline Nadine & $\mathrm{F}$ & White & 23 & BA & $15+$ & 7 & 20 & Everyday \\
\hline Thad & M & Hispanic & 21 & BA & 6 & 4 & 10 & Once weekly \\
\hline Nyles & $\mathrm{M}$ & White & 21 & 3 years & 5 & 7 & 10 & Monthly \\
\hline Larry & M & Arab & 20 & 11th grade & 3 & 5 & 17 & Once monthly \\
\hline
\end{tabular}


Table 2. Characteristics of participants: library professionals.

\begin{tabular}{|c|c|c|c|c|c|c|c|c|}
\hline Name & Gender & Race & Age & Education & $\begin{array}{l}\text { PC use } \\
\text { (years) }\end{array}$ & $\begin{array}{c}\text { Using SM } \\
\text { (years) }\end{array}$ & $\begin{array}{c}\text { Using public } \\
\text { libraries (years) }\end{array}$ & $\begin{array}{c}\text { Frequency of } \\
\text { public library use }\end{array}$ \\
\hline Holden & $\mathrm{M}$ & White & 56 & MA & 27 & 5 & $50+$ & Monthly \\
\hline Zada & $\mathrm{F}$ & White & 56 & MA & 12 & 12 & 56 & Daily \\
\hline Emmit & $\mathrm{M}$ & White & 47 & MA & 23 & 17 & 43 & Daily \\
\hline Felicity & $\mathrm{F}$ & White & 43 & $\begin{array}{c}1 \text { year } \\
\text { of college }\end{array}$ & 25 & 5 & 36 & Twice per week \\
\hline Oscar & $\mathrm{M}$ & White & 43 & MA & 35 & 3 & 40 & Daily \\
\hline Aaron & $\mathrm{M}$ & White & 36 & MA & 16 & 7 & 36 & Weekly \\
\hline Yoko & $\mathrm{F}$ & White & 36 & MA & 17 & 17 & 30 & 3 times weekly \\
\hline Magda & $\mathrm{F}$ & White & 35 & MA & 17 & 3 & 34 & Weekly \\
\hline Darla & $\mathrm{F}$ & White & 34 & MA & 15 & 10 & 30 & 3 times weekly \\
\hline Emily & $\mathrm{F}$ & White & 34 & MA & 20 & 5 & 34 & Daily \\
\hline Ulla & $\mathrm{F}$ & $\begin{array}{l}\text { African- } \\
\text { American }\end{array}$ & 34 & MA & 14 & 8 & 34 & Daily \\
\hline Quincy & M & White & 32 & $\begin{array}{c}1 \text { year } \\
\text { of college }\end{array}$ & 12 & 7 & 32 & Daily \\
\hline Adaline & $\mathrm{F}$ & $\begin{array}{l}\text { African- } \\
\text { American }\end{array}$ & 32 & MA & 16 & 5 & 27 & $1-2$ times monthly \\
\hline Fawn & $\mathrm{F}$ & White & 31 & MA & 15 & 7 & 31 & $1-2$ times monthly \\
\hline Carly & $\mathrm{F}$ & White & 31 & MA & 18 & 6 & 31 & Monthly \\
\hline Barney & $\mathrm{M}$ & White & 31 & MA & 21 & 3 & 27 & 1-3 times weekly \\
\hline Bridget & $\mathrm{F}$ & White & 31 & MA & 27 & 7 & 30 & Daily \\
\hline Phoebe & $\mathrm{F}$ & White & 31 & MA & 15 & 7 & 26 & Twice monthly \\
\hline Gail & $\mathrm{F}$ & White & 30 & MA & 20 & 10 & 30 & Once weekly \\
\hline David & $\mathrm{M}$ & White & 30 & MA & 18 & 8 & 4 & Weekly \\
\hline Uma & $\mathrm{F}$ & White & 30 & MA & 30 & 12 & 30 & Weekly \\
\hline Jody & $\mathrm{F}$ & Asian & 29 & $\mathrm{BA}$ & 10 & 10 & 21 & Weekly \\
\hline Octavia & $\mathrm{F}$ & White & 29 & MA & 10 & 7 & 25 & 1-2 times monthly \\
\hline Wallace & $\mathrm{F}$ & $\begin{array}{c}\text { Caucasian/ } \\
\text { Pacific } \\
\text { Islander }\end{array}$ & 29 & MA & 11 & 8 & 15 & Weekly \\
\hline Tatum & $\mathrm{F}$ & Asian & 29 & MA & 21 & 8 & 25 & Twice monthly \\
\hline Xandra & $\mathrm{F}$ & White & 26 & MA & 10 & 8 & 25 & Weekly \\
\hline Isaac & $\mathrm{M}$ & White & 25 & $\mathrm{BA}$ & 18 & 7 & 18 & Once a week \\
\hline Derick & M & $\begin{array}{l}\text { African- } \\
\text { American }\end{array}$ & 25 & BA & 12 & 11 & 25 & Once a month \\
\hline Hayden & M & White & 23 & $\begin{array}{c}1 \text { year } \\
\text { of college }\end{array}$ & 23 & 7 & 23 & Weekly \\
\hline Reggie & $M$ & White & 23 & $\mathrm{BA}$ & 15 & 6 & 15 & Weekly \\
\hline
\end{tabular}


The following four images (Figures 1-4) are the subject of this paper:

Because several of the individuals in the photograph are still living, the photographer of the 1971 wedding party did not feel right granting permission to me for use in publications or presentations. Interestingly, however, she posted the photograph for public consumption on Flickr [42].

Figure 1. Super Bowl XLVI, Monument Circle, Indianapolis display [43]. Photo Credit: Curtis Billue.

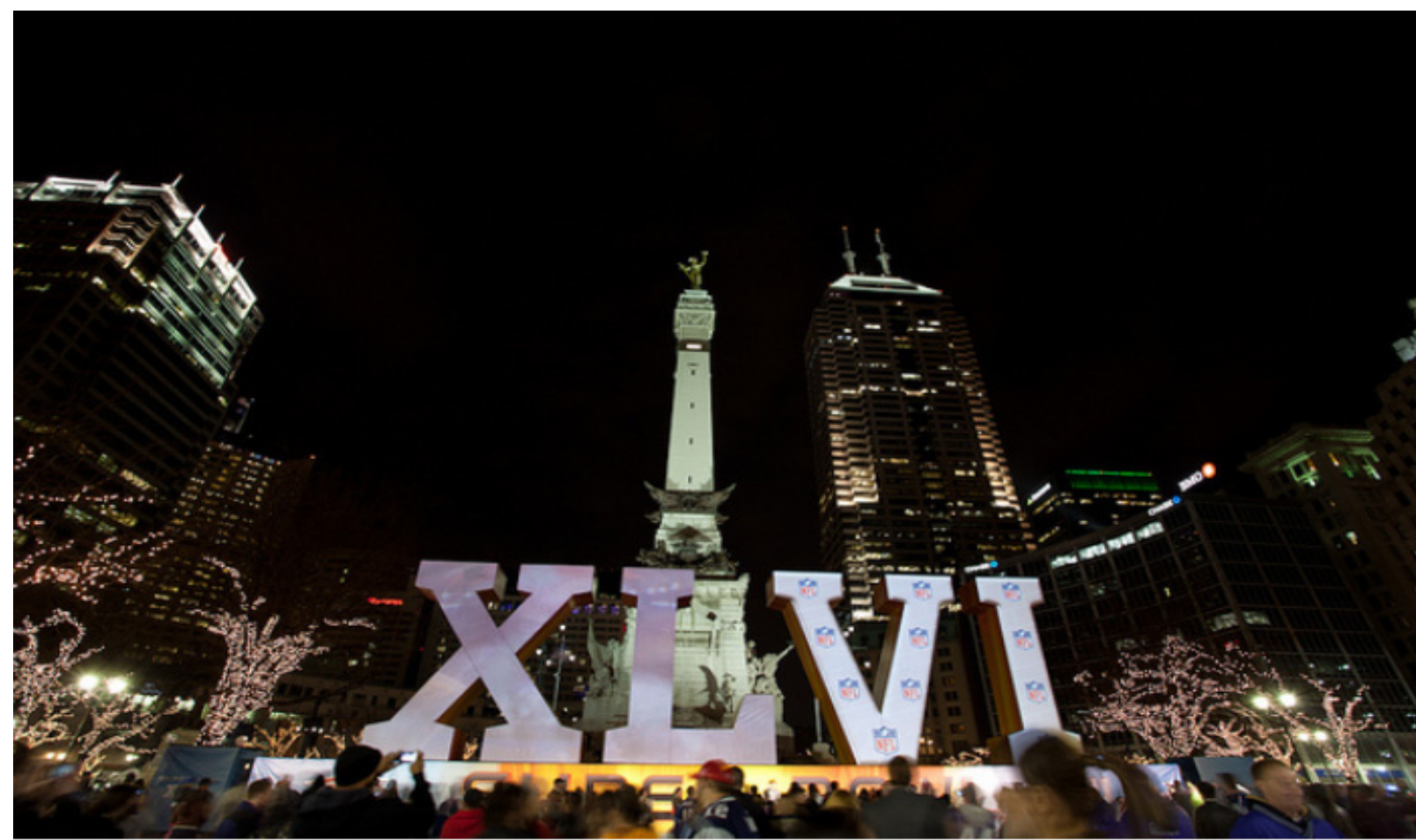

Figure 2. Grand Canyon Vista [44]. Photo Credit: Steve Dacosta.

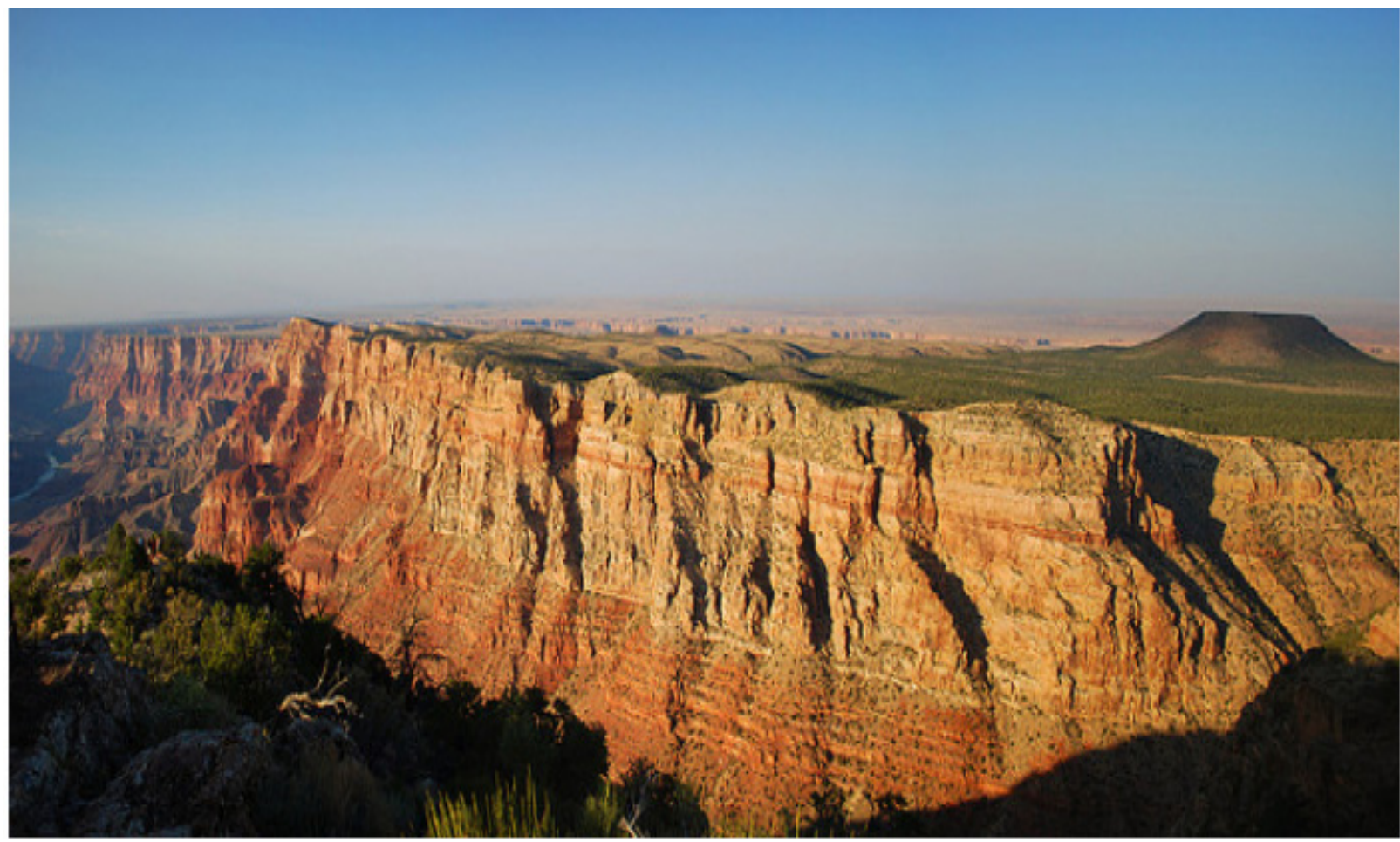


Figure 3. Abstract Art [45]. Photo Credit: Tom Tennstedt.

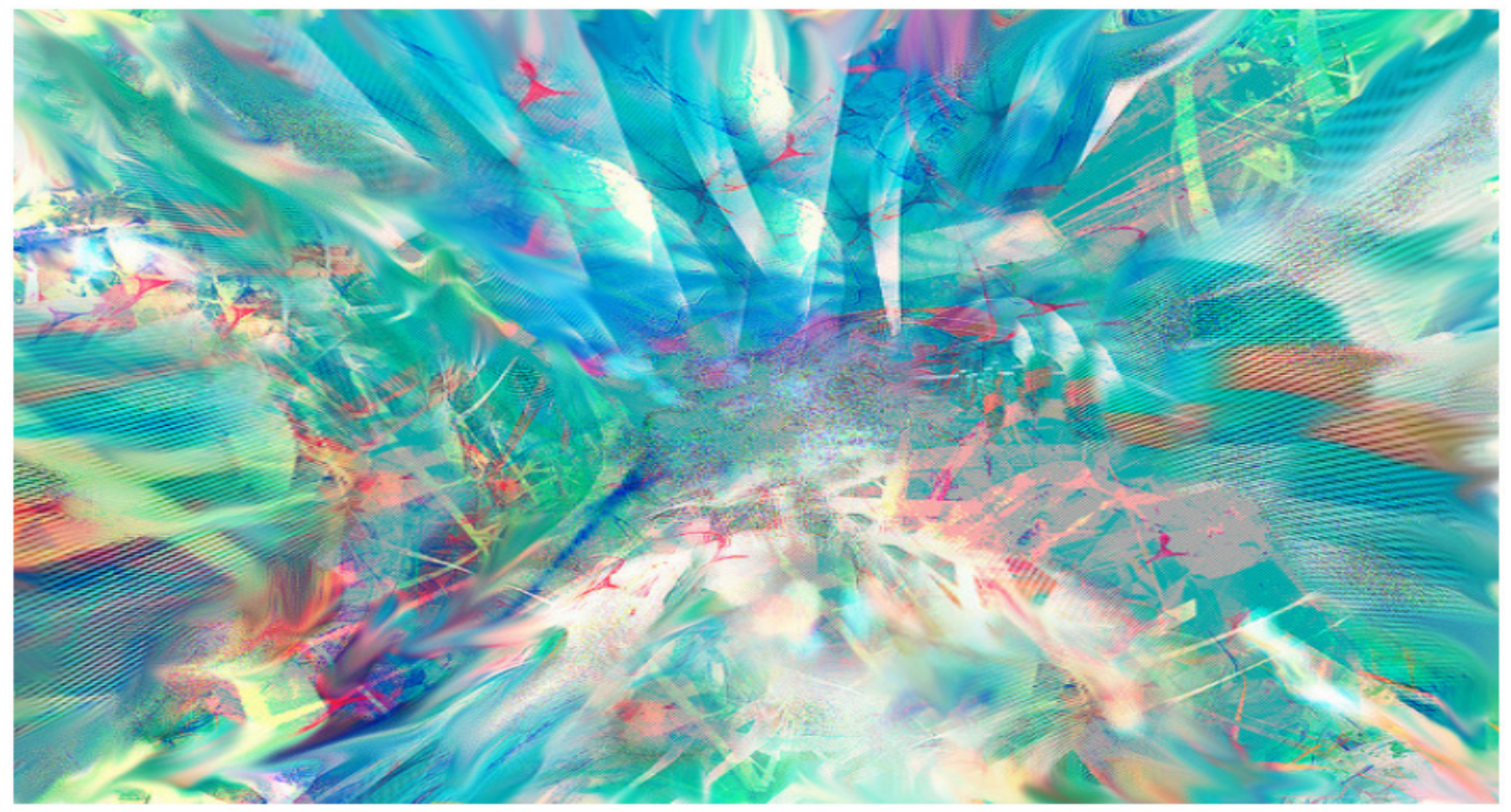

Figure 4. Grant Park, Chicago, Illinois, 2008 Election Night [46]. Photo Credit: Jerroid Marks.

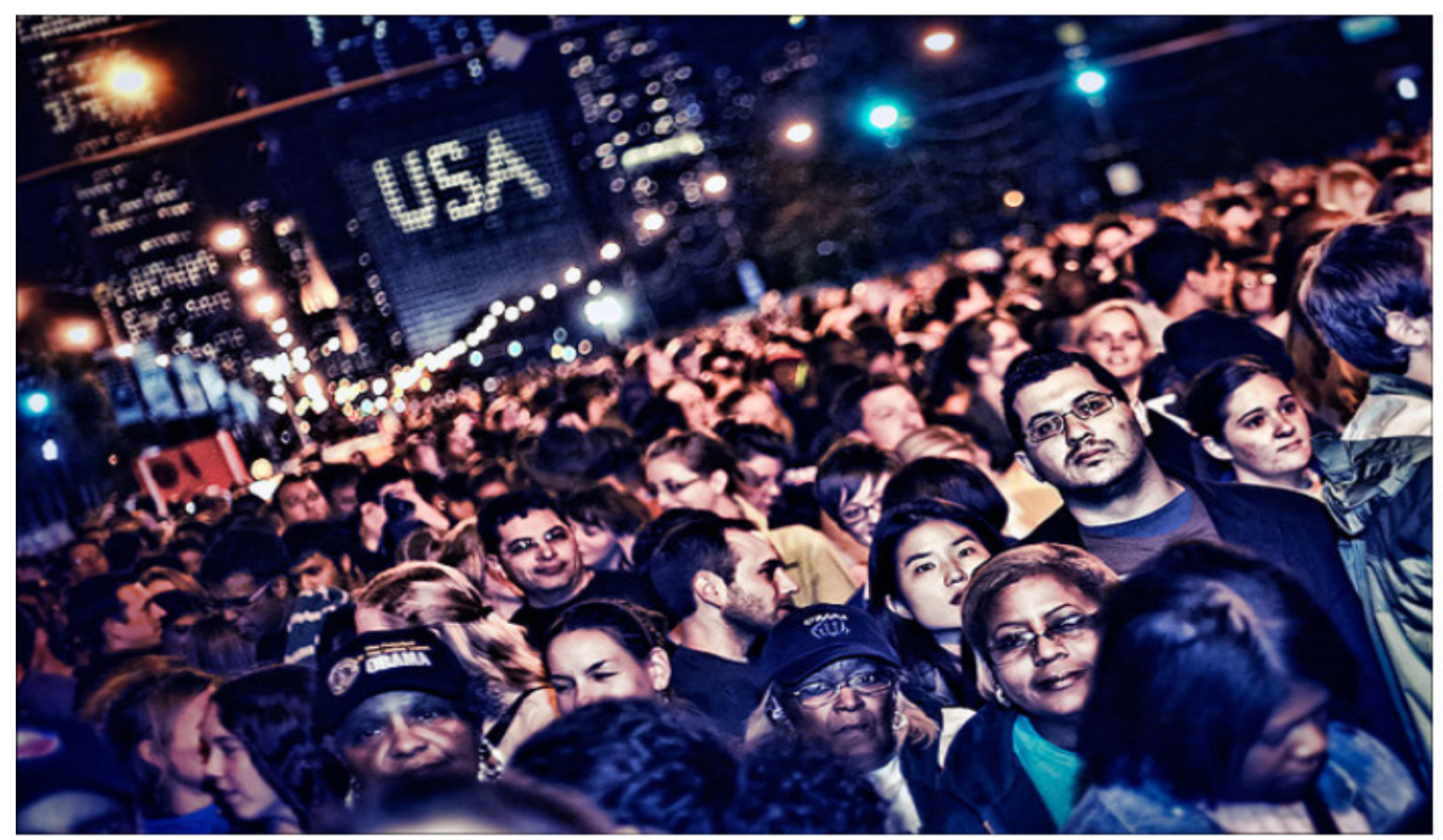

Mean scores of men and women and users and librarians were analyzed using a $t$-test with unequal variances. Averages on each of the four points (value to me; value to social history; length of preservation; and belongs in a public library digital collection) were compared for each image. Responses to the open-ended questions were organized and analyzed using NVIVO, a qualitative analysis software tool [47]. The responses were analyzed using a conventional content analysis approach. Interview transcripts were 
read several times using iterative pattern coding, which facilitates the identification of thematic patterns in the data. Saturation was reached after analyzing 27 of the transcripts.

\section{Limitations}

There are several limitations to the application of the findings presented. First, the results are not generalizable to larger populations of librarians and public library users, but are transferrable to similar populations in the United States. Secondly, while Jorgensen's 12 descriptive classes of images guided the author in selecting the images for the study, the selections were also based on the author's own knowledge of the region and United States history [48]. Lastly, while one of the goals of the study was to compare librarians and library users, it is not known to what extent the library professionals work with cultural heritage digital collections. Individuals who work outside of this realm may not be familiar with making appraisal decisions related to items representing social history, particularly as it relates to an institution's mission and collection policies. Therefore, the distinction between the two groups might be less than expected.

\section{Results}

\subsection{Quantitative Findings}

Librarians and users differed significantly regarding two of the images (Table 3). The users personally valued the photograph from Super Bowl XLVI in Indianapolis more than the librarians did. With regards to the Grand Canyon, librarians and users differed significantly with regards to the length of preservation. Since the two groups only differed significantly on two questions out of 35 , the two groups were considered together when averaging responses to the Likert scale questions for each of the images. It should also be noted that there was no statistical difference between how women and men responded on the four-point comparison for any of the images.

Table 3. Significantly different responses between users and librarians.

\begin{tabular}{cccccc}
\hline \multirow{2}{*}{ Responses } & \multicolumn{2}{c}{ Users $(\boldsymbol{N}=\mathbf{3 0})$} & \multicolumn{2}{c}{ Librarians $(\boldsymbol{N}=\mathbf{3 0})$} & \multirow{2}{*}{$\boldsymbol{*}<\mathbf{0 . 0 5}$} \\
\cline { 2 - 5 } & Mean & SD & Mean & SD & \\
\hline Super Bowl/Value to Me & 6.3 & 0.794 & 5.97 & 0.85 & 0.043 \\
Grand Canyon/Preserved Indefinitely & 5.8 & 1.215 & 4.9 & 1.936 & 0.035 \\
\hline
\end{tabular}

Figure 5 shows the relationship between value estimations. Although these images had less value to participants personally, they could see the value of the images to social history and to public library collections. Averages related to social history and inclusion in public library collections were closely scored; therefore, a positive relationship between public libraries and social history was apparent to the participants. 
Figure 5. Comparison of averages for value and inclusion in public library collections for all images from all respondents $(N=60)$.

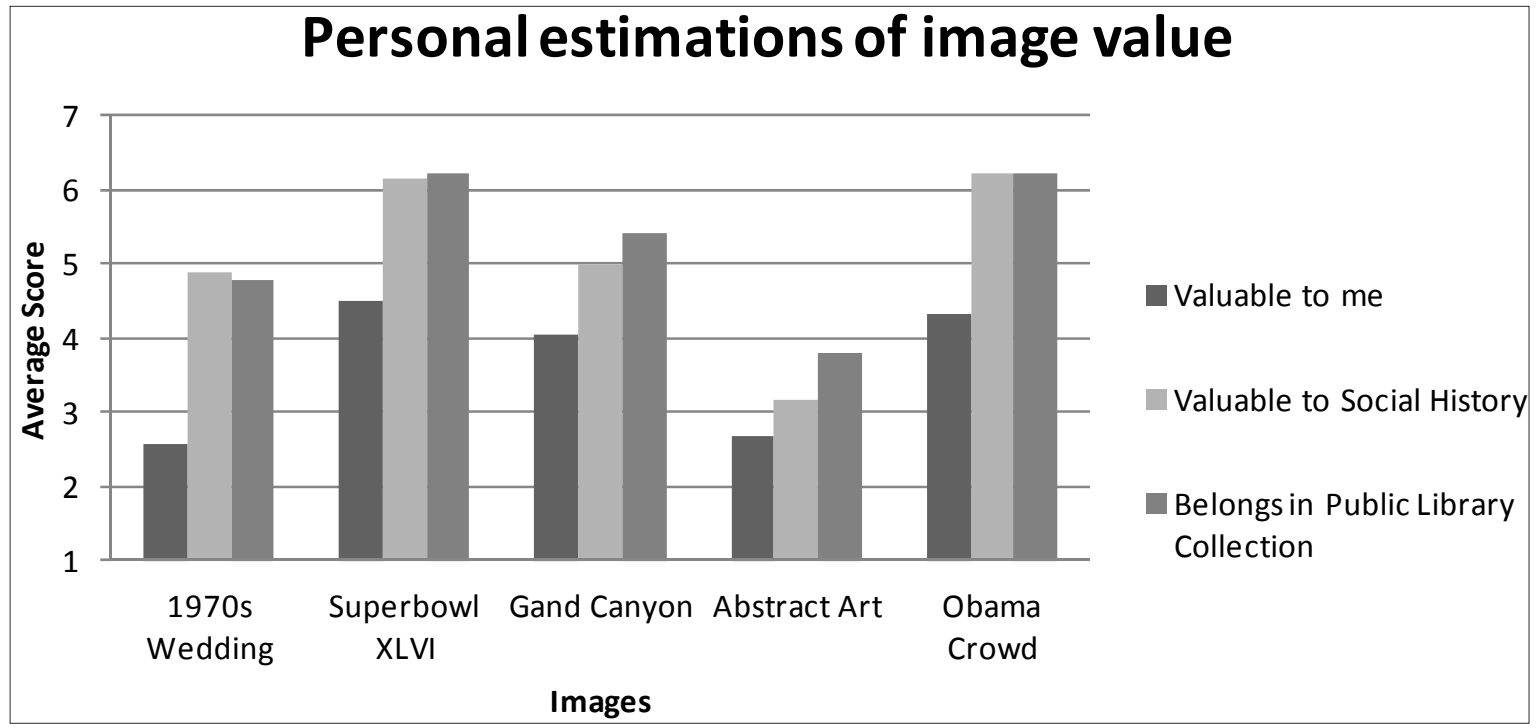

Not surprisingly, Figure 6 illustrates that participants thought most of the images should be preserved indefinitely. One participant summarized this overriding attitude by asking, "Why save it in the first place, if not forever?"

Figure 6. Comparison of averages for the various lengths of preservation for all images from all respondents. $(N=60)$.

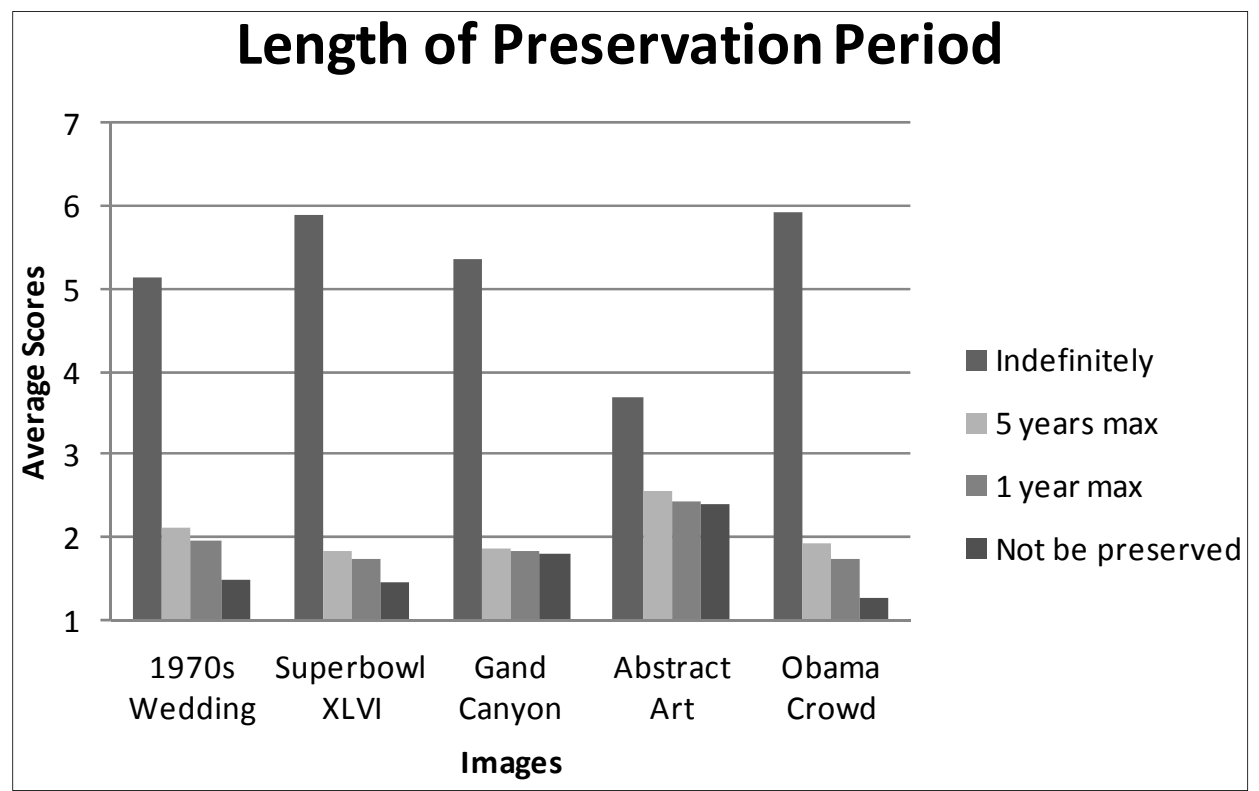

\subsection{Qualitative Findings}

\subsubsection{Wedding Photo 1971}

More often than not, individuals commented that the photograph would be valuable for documentation of time periods and the styles inherent to that time, $N=13$, rather than for genealogical purposes, 
$N=4$. The idea that this photograph should be preserved because it was an older photograph was offered by two of the participants, as their perception is that everything on the web is recent and, therefore, not as valuable. Several, $N=7$, thought that the photograph would be more valuable if the people in it were famous.

Gloria, Participant \#7: "I guess the sad thing is, is if I knew that it was a famous family, it would have more value to me. Truly."

For this photograph, a number of participants, $N=12$, felt that context was needed to increase the value of the image. More information and a contextual description was needed to determine the significance of the image.

Ethan, Participant \#31: "Possibly where it was taken. Any kind of weird details about the husband and wife. What led up to the event? Their story. That's me, interested in story."

\subsubsection{Super Bowl}

This photo was one of two where little to no value was found at the personal level, but almost all thought it was valuable for inclusion in the public library digital collection. Overwhelmingly, this photo was considered important for its documentation of place, community and the event. Some saw it as an Indianapolis-specific event, while others saw it as a national event. The participants had a similar reaction to the election night photograph of Grant Park. Interestingly, none of the participants thought additional information was needed to make the Super Bowl photo more valuable. The participants are indigenous; it is part of their personal history. Many of the participants took a similar picture. You can see many individuals in the foreground of the photo, trying for the same shot.

Gloria, Participant \#7: 'It's a Super Bowl/Indianapolis photo. It's with the numbers on the Monument Circle. And I got that picture. I took that picture. Everybody took that picture. And everybody's version of that picture should be collected."

\subsubsection{Grand Canyon}

This image elicited contrasting views: some felt it should be preserved, because it is a landmark $(N=5)$, while others thought it was such a common image that there was no need to preserve it $(N=7)$.

Barney, Participant \#54: "Well, for a collection that was on the Grand Canyon, it would make perfect sense. Or if this was about vacations that people took or something along those lines. This is a landmark, I guess, is why it really jumps out to me as being valuable in a digital collection."

Darla, Participant \#4: "Not a lot of value to me because it kind of looks like, I guess, every other picture of the Grand Canyon. You've seen one picture, you've seen 'em all. And I've personally never been there. So I don't have a personal tie to it or anything."

Carly, Participant \#55: "Possibly. I think it's pretty. I've been to the Grand Canyon. But I think, like I said with the other one, the photos that I took when I was there probably mean more to me than this, even though they might look exactly the same. There's just something about it being yours versus another photographer's. I don't know." 


\subsubsection{Abstract Image}

This image needed the most context for the participants in order for it to have value, $N=12$. Unlike the wedding photo, which could serve to document fashion from the 1970s, it did not stand on its own for most. If the image creator was famous, from the community or if they knew how it was made, then the image would have more value to them and to digital library collections.

Fawn, Participant \#58: "Well, I mean, if it was done by a famous painter or artist. Or maybe an artist from the local community might make it valuable. Yeah, I think there's more context that could make it more valuable."

Gerald, Participant \#33: "Yeah. Maybe how it was created, the programs, what it means to the artist, I always like hearing about. I also might not. (Laughter) But yeah, that sort of thing. Maybe where it was taken or I don't know if it was a photo that's amalgamated or some design program. Yes, other information could be useful for that."

\subsubsection{Grant Park}

This photo also drew mixed reactions. Some thought it was a great photograph telling the story of America, while others thought it was meaningless without a descriptive context $(N=7)$, and even then, they felt other photos of the crowd might do a better job expressing the feeling of the nation. The two statements below illustrate how some thought this image represented America, while others thought it only belonged in neighborhood collections in Chicago public libraries.

Alice, Participant \#1: “I don't know who the photographer was, what time it was taken. Maybe an article, if you could link it to an article if it appeared in an article, a newspaper article, something like that, I might read the article. But for me, it's just somebody snapped a picture that night, and who was there. Or if I was there, I might have more of an attachment to it. I'll want to remember that. But I don't. I've only been to Chicago maybe a handful of times."

Derick, Participant \#30: "Yes. Because this was the election night of the current president. And these are, I assume, all of his supporters. I see Obama things around and USA in the background. And I think it really helps capture the country's energy around this election and the excitement. And also it shows a lot of diversity within the pictures as far as ages, races, genders, ethnicities. And so, yeah, I think it's a great American photo."

\section{Discussion}

Public library users and librarians had similar value estimations of the images in the study. This is perhaps the study's most significant finding, given the importance of collaboration and forming partnerships for building and sustaining community archives. Interestingly, at no point did the author describe what digital library collections were; only one participant asked for a definition. One interpretation is that the participants assumed that creating digital collections that reflect their communities is a role for public libraries to fill. 
The participants believed that public library digital collections should have items of value pertaining to social history rather than to personal history or preference. This was indicated by the participants strongly agreeing that the Super Bowl and Grant Park images be included in collections, even though the images had little to no value to them personally. It has been asserted that individual memory becomes social memory through the act of sharing [49]. The participants' valuing of images representing historical events could be an indication of personal satisfaction, which has been generated through their participation in society and by sharing their experience with others. The images with less personal and experiential connection (the abstract design, the Grand Canyon, the 70's wedding party) were deemed less important for inclusion in public library collections.

This finding reflects the concept of prosthetic memories in that the Super Bowl and the presidential election of 2008 were experienced by many in the United States through electronic media. While the Grant Park gathering was an event experienced firsthand by a relative few, many individuals around the world witnessed it live on television. In doing so, multitudes were able to wait in quiet expectation along with the individuals physically present in the park, all eyes watching history in the making.

The participants' comments regarding the wedding photo, in which none of the subjects were famous, does not support the notion that "the people" want to encourage the development of archives that document the general populace. Given just this part of the study's findings, there appears to be support for preserving official memories representing the larger cultural history rather than the social or people's history. Further analysis of the participants' own photographs may result in a greater inclination towards preserving the history of all.

Context was requested for all of the photographs with the exception of the Super Bowl photograph from Indianapolis. The danger here is one having the belief that an image can stand on its own due to its having importance locally. Perhaps this is why so many libraries and archives have turned to crowd sourcing in order to identify photographs from local heritage sites [50]. Images are particularly challenging, for without contextualization, their meaning runs the risk of being ephemeral in nature for contemporary and participatory audiences and ambiguous for those unassociated. The act of crowd sourcing metadata speaks to the possibility of extending this practice to develop archival platforms that allow for metadata augmentation over time, as memories take on new meaning in light of new events and newly reconstructed histories.

The strong desire expressed by participants to preserve everything regardless of value poses a problem. Studies involving personal information management have found that most individuals treat all their digital content the same, regardless of value [1]. For example, many individuals report backing all their content up rather than just items they deem important. Is it a matter of difficulty in anticipating a future information need [51], or is it a matter of the ease of digital information creation outpacing the time it takes to organize and describe information [52]? Regardless of the reasoning, careful selection and appraisal of information will have to guide public library digital collections, as storage, organizational efforts and preservation resources are neither endless nor free of cost.

A photograph can speak a thousand words; however, without an accompanying narrative, over time, the photograph may be rendered speechless, owing to the loss of context and audience. With regards to the archival processing of photographs, this study offers the insight that it is perhaps more important with photographs than with any other media to collect the narrative as the photograph is created in order to capture the textual narrative experience along with the visual. This is especially important 
regarding experiences related to the people's history, as this history is often not captured in more formal ways, and as such, there will be fewer resources to ascertain their meaning years hence. The people hold the meaning. Halbwachs discusses the effect of place and group imprinting upon another in relation to the spatial framework in which events occur [53]. It is important to grasp the views of people inhabiting that space while they are in it. He points out that life events are merged with objects, buildings, things; one is not realized without the other. To better document events that occur within a community space through photographic representations, the human experience needs to be captured simultaneously. This is a challenging proposition, especially when one considers the growing influence of prosthetic memories on the human narrative.

\section{Conclusions}

This study shows that support exists for valuing, collecting and preserving publicly available images representing social history and that there are roles for public libraries and their communities to fill in this process. Digital image collections are not as common in public libraries as they are in academic libraries. Currently, few public library digital collections exist that are created in collaboration with library users to document the places, events and lives of its community members. In the future, it is likely that public library digital collections will not only reflect the library's community and its individual members, but also be created by them. More research is needed to make this happen, particularly in the areas of privacy, technology infrastructure and content representation.

\section{Acknowledgments}

This research was supported through funding from IUPUI's Developing Diverse Researchers with InVestigative Expertise Grant. I would like to thank the IUPUI University Library for supporting open access publishing, including this paper. Furthermore, I would like to thank the reviewers for their insightful feedback and Tom McDowell for his editing assistance, all of which contributed to a stronger paper.

\section{Conflicts of Interest}

The author declares no conflict of interest.

\section{References}

1. Copeland, A. Analysis of public library users' digital preservation practices. J. Am. Soc. Inf. Sci. Technol. 2011, 62, 1288-1300.

2. Cushing, A. A balance of primary and secondary values: Exploring a digital legacy. Int. J. Knowl. Content Dev. Technol. 2013, 3, 67-94

3. Smith, A. Valuing preservation. Libr. Trends 2007, 56, 4-25.

4. Terras, M. The digital wunderkammer: Flickr as platform for amateur cultural and heritage content. Libr. Trends 2011, 59, 686-706. 
5. Garde-Hansen, J. MyMemories? Personal digital archive fever and Facebook. In Digital Memory Practices; Garde-Hansen, J., Hoskins, A., Reading, A., Eds.; Palgrave Macmillan: New York, NY, USA, 2009; pp. 135-150.

6. Good, K.D. From scrapbook to Facebook: A history of personal media assemblage and archives. New Med. Soc. 2013, 15, 557-573.

7. Kennedy, L.; Naaman, M.; Ahern, S.; Nair, R.; Rattenbury, T. How flickr helps us make sense of the world: Context and content in community-contributed media collections. In Proceedings of the Annual Meeting of ACM Multimedia in Augsburg, Bavaria, Germany, 23-28 September 2007.

8. Copeland, A.J.; Barreau, D. Helping people to manage and share their digital information: A role for public libraries. Libr. Trends 2011, 59, 637-649.

9. Bradley, K. Defining digital sustainability. Libr. Trends 2007, 56, 148-163.

10. Mason, I. Cultural information standards-Political territory and rich rewards. In Theorizing Digital Cultural Heritage; Cameron, F., Kenderdine, S., Eds.; MIT Press: Cambridge, MA, USA, 2007; pp. 223-244.

11. Japzon, A.J. A Model of and Support for a Digital Preservation Infrastructure that Connects Individuals to Libraries. In Proceedings of the World Library and Information Congress, 74th General Conference and Council, Québec, Canada, 10-14 August 2008. Available online: http://www.ifla.org/IV/ifla74/papers/084-Japzon-en.pdf (accessed on 10 February 2014).

12. Flinn, A. Community histories, community archives: Some opportunities and challenges. J. Soc. Arch. 2007, 28, 151-176.

13. Flinn, A. Archival activism: Independent and community-led archives, radical public history and the heritage professions. InterActions 2011, 7. Available online: http://escholarship.org/uc/item/ 9pt2490x (accessed on 13 May 2014).

14. Van Wingen, M. Reappraising archival practice in light of the new social history. Libr. Hi Tech 2008, 26, 575-585.

15. Gray, V. "How's that knocking on our door?" Archives, Outreach, and Community. J. Soc. Arch. 2008, 29, 1-8.

16. Eales, K. Community archives: Introduction. S. A. Arch. J. 1998, 40, 11-15.

17. Shilton, K.; Srinivasan, R. Participatory appraisal and arrangement for multicultural archival collections. Archivaria 2007, 63, 87-101.

18. Hall, M.H.; Reed, P.B. Shifting the burden: How much can government download to the non-profit sector? Can. Public Adm. 1998, 41, 1-20.

19. Marinetto, M. Who wants to be an active citizen? The politics and practice of community involvement. Sociology 2003, 37, 103-120.

20. Urban Libraries Council. The Engaged Library: Chicago Stories of Community Building. Available online: http://www.abcdinstitute.org/docs/ULCReport.pdf (accessed on 10 February 2014).

21. Gong, H.; Japzon, A.; Chen, C. Public libraries and social capital in three New York City neighborhoods. Tijdschr. Econ. Soc. Geogr. 2008, 99, 65-83.

22. Senville, W. Libraries at the heart of our communities. Plan. Comm. J. 2009, 75, 12-17. 
23. Hoffman, J.; Bertot, J.; Davis, D. Libraries Connect Communities: Public Library Funding \& Technology Access Study 2011-2012. Digital Supplement of American Libraries Magazine, June 2012. Available online: http://viewer.zmags.com/publication/4673a369 or http://www.ala.org/ research/plftas/2011_2012 (accessed on 13 May 2014).

24. ALA Digital Content Working Group. Public Libraries as Publishers; Draft of 16 September 2013; ALA: Chicago, IL, USA, 2013.

25. Neiburger, E. The end of the public library. (As we knew it)? In Book: A futurist's Manifesto; McGuire, H., O’Leary, B., Eds.; O’Reilly: Boston, MA, USA, 2012; pp. 269-275.

26. Library Publishing Toolkit; Brown, A.P., Ed.; IDS Project Press, Milne Library: SUNY Geneseo, NY, USA, 2013.

27. Farkas, M. Community Creativity. Enabling Local Publishing in Libraries. American Libraries Magazine, September/October 2013. Available online: http://www.americanlibrariesmagazine. org/article/community-creativity (accessed on 10 February 2014).

28. Lipinski, T.; Copeland, A. Look before you license: The use of public sharing websites in building patron initiated public library repositories. Preserv. Digit. Technol. Cult. 2013, 42, 174-198.

29. Chen, S.-S. The paradox of digital preservation. Computer 2001, 34, 24-28.

30. Community Archives and Heritage Group. Available online: http://www.communityarchives.org.uk/ (accessed on 30 January 2014).

31. Grabowski, J. Fragments or components: Theme collections in a local setting. Am. Arch. 1985, 48, 304-314.

32. Kunda, S.; Anderson-Wilk, M. Community stories and institutional stewardship: Digital curation's dual roles of story creation and resource preservation. Portal: Libr. Acad. 2011, 11, 895-914.

33. Flinn, A.; Stevens, M.; Shephard, E. Whose memories, whose archives? Independent community archives, autonomy and the mainstream. Arch. Sci. 2009, 9, 71-86.

34. Johnston, I. Whose history is it anyway? J. Soc. Arch. 2001, 22, 213-229.

35. Keough, B. Documenting diversity: Developing special collections of underdocumented groups. Libr. Collect. Acquis. Tech. Serv. 2002, 26, 241-251.

36. Wakimoto, D.K.; Bruce, C.; Partridge, H. Archivist as activist: Lessons from three queer community archives in California. Arch. Sci. 2013, 13, 293-316.

37. Wedgwood, T. History in two dimensions or three? Working class response to history. Int. J. Herit. Stud. 2013, 15, 277-297.

38. Sontag, S. On Photography; Farrar, Straus, \& Grioux: New York, NY, USA, 1977.

39. Landsberg, A. Memory, empathy, and the politics of identification. Int. J. Polit. Cult. Soc. 2009, 22, 221-229.

40. Schwartz, J. Coming to terms with photographs: Descriptive standards, linguistic "Othering," and the margins of archivy. Archivaria 2002, 54, 142-171.

41. Schlak, T. Framing photographs, denying archives: The difficulty of focusing on archival photographs. Arch. Sci. 2008, 8, 85-101.

42. Beth, K. Wedding Party 1971. Available online: http://www.flickr.com/photos/42304632@N00/ 2618543501/ (accessed on 8 February 2014).

43. Billue, C. Indianapolis Super Bowl XLVI. Available online: http://www.flickr.com/photos/ curtispic/6815050069/ (accessed on 8 February 2014). 
44. Dacosta, S. Panorama of Desert View, Grand Canyon. Available online: http://www.flickr.com/ photos/dacosta85/4406011602/in/set-72157626354849913 (accessed on 20 April 2014).

45. Tennstedt, T. Abstract Colorful Universe Wallpape. Available online: http://www.flickr.com/ photos/ttdesign/2558614528/ (accessed on 9 February 2014).

46. Marks, J. Grant Park Crush. Available online: http://www.flickr.com/photos/pickedandshuttered/ 3006583031/ (accessed on 9 February 2014).

47. QSR NVivo, Version 10. QSR International, Burlington, MA, 2014.

48. Jorgensen, C. Attributes of images in describing tasks. Inf. Process. Manag. 1998, 34, 161-174.

49. Ketelaar, E. Sharing: Collected memories in communities of records. Arch. Manuscr. 2005, 33, 44-61.

50. Holley, R. Crowdsourcing: How and why libraries should do it. D-Lib Mag. 2010, 16, doi:10.1045/march2010-holley. Available online: http://www.dlib.org/dlib/march10/holley/ 03holley.html (accessed on 31 January 2014).

51. Bruce, H. Personal, anticipated information need. Inf. Res. 2005, 10. Available online: http://informationr.net/ir/10-3/paper232 (accessed on 31 January 2014).

52. Boardman, R.; Sasse, M.A. Stuff goes into the computer and doesn't come out. A cross-tool study of personal information management. In Proceedings of the ACM 2004 Conference on Human Factors in Computing Systems (CHI), Vienna, Austria, 24-29 April 2004; Dykstra-Erickson, E., Tscheligi, M., Eds.; ACM Press: New York, NY, USA, 2004; pp. 583-590.

53. Halbwachs, M. Space and the collective memory. In The Collective Memory; Harper \& Row: New York, NY, USA, 1980.

(C) 2014 by Andrea J. Copeland; licensee MDPI, Basel, Switzerland. This article is an open access article distributed under the terms and conditions of the Creative Commons Attribution license (http://creativecommons.org/licenses/by/3.0/). 